\title{
Sales Drive Advertising Expenditures: Evidence for Consumer Packaged and Durable Goods in Germany
}

\author{
Juliane A. Lischka ${ }^{1}$, Stephanie Kienzler ${ }^{1} \&$ Ulrike Mellmann $^{1}$ \\ ${ }^{1}$ Institute of Mass Communication and Media Research, University of Zurich, Switzerland \\ Correspondence: Juliane A. Lischka, Institute of Mass Communication and Media Research, University of \\ Zurich, Andreasstrasse 15, 8050 Zurich, Switzerland. Tel: 41-44-635-2075. E-mail: j.lischka@ipmz.uzh.ch
}

\author{
Received: October 8, 2013 Accepted: November 1, 2013 Online Published: January 22, 2014 \\ doi:10.5539/ijms.v6n1p31 URL: http://dx.doi.org/10.5539/ijms.v6n1p31
}

\begin{abstract}
The relation between sales and advertising is both complex and diverse. Whether advertising activities drive or follow sales is still unclear. We uncover this relation distinguishing between consumer packaged goods (CPG) and durable consumer goods (DCG) industries. We fit vector autoregressive models to sales and advertising expenditures of four CPG and three DCG industries in Germany from 1991 q1 to 2009 q4. Findings reveal that advertising expenditures do not increase total sales of industries according to the distribution hypothesis. According to the deterministic view, advertising budgeting is often influenced by previous sales and partly by future sales expectations. We conclude that past sales and partly sales expectations may change company and marketing goals that eventually affect the use of strategic communication instruments such as advertising.
\end{abstract}

Keywords: advertising budgeting, advertising spending, sales response, activist view, deterministic view, manufacturing industry, organizational behavior, marketing strategy, business cycle

\section{Introduction}

Advertising can be understood as a sub-discipline of strategic communication "which is defined as the purposeful use of communication by an organization to fulfill its mission" (Hallahan, Holtzhausen, van Ruler, Verčič, \& Sriramesh, 2007, p.3). For businesses, the economic value of advertising is to the fore and its impact on performance indicators such as consumption or sales has been widely discussed (Brierley, 2006; Dutt, 2008; Turner, 2000; Wilkie \& Moore, 2007). Current knowledge indicates a complex relation between sales and advertising. However, from both a theoretical and empirical point of view, no conclusion can be reached regarding the direction of influence. Two assumptions about the advertising-sales relation are in conflict. First, the activist view states that advertising stimulates demand and therefore causes sales. Additionally, the distribution hypothesis predicts no impact of advertising on sales on an aggregate level (Simon, 1970). From this perspective, advertising can only drive sales within a market or industry. Second, the deterministic view expects that higher sales lead to higher advertising expenses. This idea conforms to the practitioners' rule of thumb to use a certain share of past sales for advertising expenditures. Therefore, sales should drive advertising. In this regard, scholars showed that advertising expenditures lead sales, consumption, or GDP (see e.g., Taylor and Weiserbs 1972 as well as Molinari and Turino 2006 for U.S. data, Rehme and Weisser 2007 for German data). However, others find the exact opposite, i.e., a causal relation from consumption to advertising expenditures (see e.g., Quarles and Jeffres 1983 in a cross-national study; Ashley et al. 1980 and Hsu et al. 2002 for U.S. data; O’Donovan et al. 2000 for New Zealand data).

We argue that one of the reasons for the ambiguities could be ascribed to the high level of data aggregation that might obscure differences in the advertising-sales relation for different industries. We therefore suggest analyses on meso, i.e., industry level. Our research objective is to disclose the advertising-sales relation for product groups with long and short purchase frequencies on industry level. By doing so, we pick up on a connotation of the distribution hypothesis stating that advertising can affect sales only within a sector or product category. Additionally, we take into account that properties of durable versus consumer packaged goods differ considerably which affects consumers' buying habits, advertisings' effectiveness, and firms' advertising behaviour, accordingly. Last but not least, since none of the above mentioned frameworks (activist vs. deterministic view, distribution hypothesis) acknowledges diametrical developments of advertising and sales curves, we incorporate research on the usage of advertising decision models. Future-oriented budget setting 
approaches can explain why sales and advertising might not develop in alignment with each other.

Empirically, we analyse the direction and strength of the relation between advertising and sales with quarterly data on four consumer packaged goods (CPG) and three durable consumer goods industries (DCG) in Germany. The study's goals are 1) to provide a more detailed picture about the advertising-sales relation by focusing on industry level data instead of national level data, and 2) to provide empirical evidence for or against the assumption that advertising behaviour differs between industries due to differences regarding the properties of goods and advertisers' budgeting strategies, accordingly.

The article is structured as follows: First, we discuss previous findings on the activist and deterministic view on the advertising-sales relation and contrast these views with advertising budgeting practices. Second, we discuss different product characteristics and consumer behaviour of CPG and DCG and findings on the advertising-sales relation on industry level. From this discussion, we derive a hypothesis and a research question. Data and analyses are explained in section 4 . Results are described in section 5 and discussed in section 6 . We summarize and draw conclusions in section 7 .

\section{Literature Review}

\subsection{Research on National Level}

\subsubsection{Activist vs. Deterministic View}

The activist point of view regards advertising as a tool to activate demand by diffusion of knowledge and influencing consumers' inter-temporal preferences (Bagwell, 2001; Jones, 2007; Kopf, Torres, \& Enomoto, 2011). Studies on industry level assume that advertising persuades customers to purchase (Balasubramanian \& Kumar, 1990; Jolodar \& Ansari, 2011) - and this assumption is also widespread among marketing practitioners (Ewing \& Jones, 2000). When advertising activities or expenditures increase, sales will increase as well. The deterministic view, however, assumes that higher sales lead to more advertising activities and vice versa: "whenever manufacturers realize more revenues from sales, they tend to spend more on advertising" (Hsu et al., 2002, p.187). This deterministic assumption is affirmed by studies showing a strong economic dependency of advertising expenditures on a national level (Ashley et al., 1980; Deleersnyder, Dekimpe, Steenkamp, \& Leeflang, 2009; Hsu et al., 2002; O'Donovan et al., 2000; Picard, 2001; Quarles \& Jeffres, 1983; Tellis \& Tellis, 2009). Yet other studies on a national level show that advertising expenditures are pro-actively leading consumption according to the activist view (Lamdin, 2008; Molinari \& Turino, 2006; Rehme \& Weisser, 2007; Sturgess \& Wilson, 1984; Taylor \& Weiserbs, 1972). In addition to one-directional relations, there is evidence of a two-way causality (Jung \& Seldon, 1995) or no causality at all (Chowdhury, 1994).

Moreover, some studies do not consider advertising as being able to increase total consumption. Rather, advertising "does no more than affect how people 'spread around' the sum they make available for spending" (Simon, 1970, p.204). According to this distribution hypothesis, advertising expenditures allocate consumption only across products or services within a single category or sector, rather than increase aggregate consumption within the economy (Broadbent, 2008; Chowdhury, 1994). This is because an increase in advertising by one company may reduce the sales of competitors who may then react with an increase in their own advertising activities (Galbraith, 1967, p. 216; Bagwell, 2001, p.30).

To sum up, the activist and deterministic view explain the following scenarios: When, according to empirical evidence, advertising expenditures precede sales, this could be interpreted as evidence

a) for the activist view: If advertising activities increase (decrease), sales increase (decrease) as a result.

When, according to empirical evidence, advertising expenditures follow sales, this could be interpreted as evidence

b) for the deterministic view: If sales increase (decrease), advertising expenditures can increase (decrease) as a result.

However, macro level analyses did not provide a clear answer to the advertising-sales relation. Both the activist and the deterministic view lack an explanation for anti-cyclical advertising and other cases when advertising expenditures increase but sales decrease and vice versa.

\subsubsection{Advertising Budgeting Practices}

The advertising budgeting process can be described as decision making under uncertainty (Farris \& Buzzell, 1979; Farris, Verbeke, Mdickson, \& van Nierop, 1998; Kienzler \& Lischka, 2013) and is based on decision maker's beliefs and data (Hutchinson, Alba, \& Eisenstein, 2010, p.627). Reviewing advertising budgeting practices, not only past but also expected sales influence the amount of advertising expenditures. Whereas 
advertising budgeting methods used to be rather unsophisticated up to the $1980 \mathrm{~s}$ and based on percentage-of-sales or affordable amount of money, more complex methods such as the objective-task method has been increasingly used particularly amongst large companies (Cheong, Kim, \& Kim, 2013; Helgesen, 1992; Hung \& West, 1991). To set advertising budgets, past-oriented methods such as the affordable or percentage-of-sales method, but also present-oriented such as the competitive or unit sales method, and future-oriented such as anticipated sales or objective-task methods are used (see Table 1).

Table 1. Use of past-, present-, or future-oriented advertising budgeting methods

\begin{tabular}{|c|c|c|c|c|c|c|c|c|c|}
\hline & Judgment & Measurement & Judgment & Competitive & Sales & Competitive & Sales & Sales & Objective-task \\
\hline & Arbitrary & & Affordable & Competitive/absolute & $\begin{array}{l}\% \text { of last } \\
\text { year's sales }\end{array}$ & Competitive/relative & $\begin{array}{l}\% \text { of anticipated } \\
\text { sales }\end{array}$ & Unit sales & Objective-task \\
\hline $\begin{array}{l}\text { Advertising } \\
\text { budgeting method } \\
\text { (Cheong, Kim, \& } \\
\text { Kim, 2013) }\end{array}$ & $\begin{array}{l}\text { Based on } \\
\text { what is } \\
\text { 'felt' to be } \\
\text { necessary }\end{array}$ & $\begin{array}{l}\text { Use of } \\
\text { mathematical } \\
\text { techniques }\end{array}$ & $\begin{array}{l}\text { An 'all you } \\
\text { can afford' } \\
\text { approach }\end{array}$ & $\begin{array}{l}\text { The budget is set in line } \\
\text { with the market share }\end{array}$ & $\begin{array}{l}\text { Set } \% \text { of sales } \\
\text { from the } \\
\text { previous } \\
\text { financial year }\end{array}$ & $\begin{array}{l}\text { The budget is set in } \\
\text { line with that of your } \\
\text { closest rival }\end{array}$ & $\begin{array}{l}\text { Set } \% \text { of the } \\
\text { firm's } \\
\text { anticipated sales }\end{array}$ & $\begin{array}{l}\text { A fixed } \% \text { of the } \\
\text { unit price } \\
\text { multiplied by } \\
\text { the projected } \\
\text { sales volume }\end{array}$ & $\begin{array}{l}\text { Spending is in } \\
\text { accordance with } \\
\text { what is required to } \\
\text { meet the } \\
\text { objectives }\end{array}$ \\
\hline Time reference & $\begin{array}{l}\text { not } \\
\text { applicable }\end{array}$ & not applicable & Result of past & Result of past & Past & Present & Future & Future & Future \\
\hline & $\%$ & $\%$ & $\%$ & $\%$ & $\%$ & $\%$ & $\%$ & $\%$ & $\%$ \\
\hline $\begin{array}{l}\text { Cheong et al. } \\
(2013, p .45), \\
\text { U.S., n = } 169 \\
\text { marketing } \\
\text { managers }\end{array}$ & 46.1 & 12.0 & 57.5 & 4.8 & 19.8 & 11.4 & 16.8 & 5.4 & 41.9 \\
\hline $\begin{array}{l}\text { Prendergast et al. } \\
\text { (2006, p. 171), } \\
\text { China, } n=206 \\
\text { advertisers }\end{array}$ & 27.2 & 28.6 & 62.6 & 7.3 & 28.2 & 26.2 & 44.2 & 21.4 & 38.8 \\
\hline $\begin{array}{l}\text { West and } \\
\text { Prendergast } \\
(2009, \text { p. } 1465) \\
\text { UK, } n=77 \\
\text { advertisers }\end{array}$ & 6.5 & 20.8 & 20.7 & 0.7 & 2.6 & 6.5 & 9.0 & 2.6 & 23.9 \\
\hline Mean & 26.6 & 16.4 & 46.9 & 4.3 & 16.9 & 14.7 & 23.3 & 9.8 & 34.9 \\
\hline $\begin{array}{l}\text { Advertising-sales } \\
\text { relation will } \\
\text { provide support } \\
\text { for ... }\end{array}$ & $\begin{array}{l}\text { no clear lead } \\
\text { relation }\end{array}$ & ing/lagging & \multicolumn{2}{|c|}{ deterministic view* } & & $\begin{array}{l}\text { no clear leading/ } \\
\text { lagging relation }\end{array}$ & activist view ${ }^{* *}$ & & \\
\hline
\end{tabular}

Of these methods, the past-oriented affordable methods as well as the future-oriented methods are used most often supporting either the deterministic or the activist view. However, the budgeting has to occur pro-cyclical with the sales development and future sales expectations have to be correct. Otherwise, no positive advertising-sales relation will be detected from data analyses. Further, the arbitrary, the measurement and the present-oriented budgeting setting method may not reveal an advertising-sales relation at all. If advertisers expect fewer sales e.g. due to economic crises, they might cut down their advertising budgets. However, anti-cyclical advertising strategies would lead to an increase of advertising expenditures during crises. Therefore, the chronological cause-and-effect-chain of the advertising-sales relation is reversed. If sales expectations are taken into account, new interpretations for empirical results on advertising-sales relations emerge. Keeping in mind, that managers' assumptions on sales development can be correct or incorrect, the following scenarios are conceivable: 
When, according to empirical evidence, advertising expenditures precede sales, this could be interpreted as evidence

c) for a future-oriented pro-cyclical budget setting approach: If advertisers expect fewer (more) sales, they will cut down (increase) their advertising budgets. If their assumptions are correct, sales will drop (increase) accordingly. If sales rise (decrease) unexpectedly, their assumptions have been incorrect.

d) for a future-oriented anti-cyclical budget setting approach: If advertisers expect fewer (more) sales, they will increase (decrease) their advertising budgets. If their assumptions are correct, sales will increase (drop) accordingly. If sales decrease (rise) unexpectedly, their assumptions have been incorrect.

I. e., although the activist point of view prompt the perception that advertising budgets are set independently from past sales, quite the reverse could be true.

When, according to empirical evidence, advertising expenditures follow sales, this could be interpreted as evidence

e) for a past-oriented advertising budgeting setting method predicted by the deterministic view: If advertisers realized more (fewer) sales in the past they can afford to spend more (less) for advertising in the future.

Figure 2 summarizes the five scenarios a) to e) for the temporal relation of advertising and sales.

\subsection{Research on Industry Level}

Advertising-sales relations differ on product or industry level because of different product characteristics and consumer behaviour. As shown in Figure 1, CPG and DCG differ in terms of their useful life, their need of explanation, frequency of purchase, consumers' buying behavior and their perception of the purchase (Leischner, 2009, p. 1080; Murphy \& Enis, 1986). CPG have a short useful life and they are more or less self-explanatory and bought regularly and often (Broadbent, 2009, p. 163). Prices of CPG are-in relation to a household's disposable income-low (Berndt, 2005, p. 27). Thus, sellers generate benefits through high sales volumes and try to maintain consumer's loyalty through strong brands (Broadbent, 2009, pp. 162-163). Whereas the initial purchase of a specific CPG that is new to the customer demands some conscious decision making, subsequent purchases of the same brand are routine and habitual — provided that the customer was satisfied with the product. DCG have a longer useful life, are substantially more expensive, and are bought less frequently. Because of the lacking routine of purchases and especially due to the higher costs, buying DCG is perceived as risky (Grewal, Mehta, \& Kardes, 2004, p. 110). Consequently, customers engage themselves in an extensive and complex purchase decision with a high level of involvement, i.e., they search and process information actively (Kotler, Keller, \& Bliemel, 2007, p. 292). As activists consider advertising as means to provide information, advertising could create demand and finally sales for DCG. At the same time, durable sales depend on income (McCollough, 2007) and the economic situation (Cook, 1999; Dhawan \& Jeske, 2008; King \& Rebelo, 1999; Krishna \& Yavas, 2004; Power, 2004; Stock \& Watson, 1999). Whereas CPG are necessities, the purchase of DCG can be postponed (see e.g., Bryant \& Zillmann, 1994, pp. 17-18; Petersen \& Strongin, 1996, p. 190). Hence, sales for DCG should more strongly depend on household income than for CPG. Also the advertising strategy and budgeting should follow different patterns between CPG and DCG.

Studies that differentiate among product characteristics find different advertising elasticities depending on purchase frequency of products. Previous studies reported short- or long term advertising elasticities for different product categories depending on purchase frequency (e.g. Sethuraman et al. 2011 for food, nonfood, pharmaceutics, durables, and service on firm level data, Draganska and Klapper 2011 for German coffee brands, Fischer and Albers 2010; Cavusgil and Calantone 2011 for pharmaceutics on brand level). Sethuraman et al. (2011) summarize in a meta-analysis that the advertising elasticity is high for durable goods, followed by pharmaceutics and service goods. Frequently purchased, low-involvement food and nonfood products have the lowest advertising elasticity (Sethuraman et al., 2011, p. 466). On industry level, however, Engle and Ambler (2002) find no significant relation between advertising and market growth for chocolate markets. Also, Wilcox et al. (2009) cannot reveal a relationship between aggregate soft drink advertising expenditures and soft drink consumption. But Andrews and Franke (1991) report a positive advertising elasticity for tobacco in Germany in the 1960s and 1970s using data on an industry level. They also show that the advertising elasticity decreased over time.

Thus, previous research on industry level shows evidence for different advertising-sales relations across industries. However, only the activist view is considered within previous industry studies and a possible deterministic relation is ignored.

In difficult economic times, consumers tend to cut back their spending, i.e., to increase their saving rates (Kaytaz 
\& Gul, 2014; evidence for Germany in Poser, 1983, p. 167). Lamey et al. (2007, p. 3) conclude, that particularly "at the beginning of a recession, consumers have a strong incentive to limit their spending and wait for better times." However, these cuts are not spread equally among all product categories, but rather affect DCG than CPG due to their different product characteristics. Consumer spending is influenced by income and consumer confidence which in turn depend on the economic climate (Quelch \& Jocz, 2009; Kaytaz \& Gul, 2014).

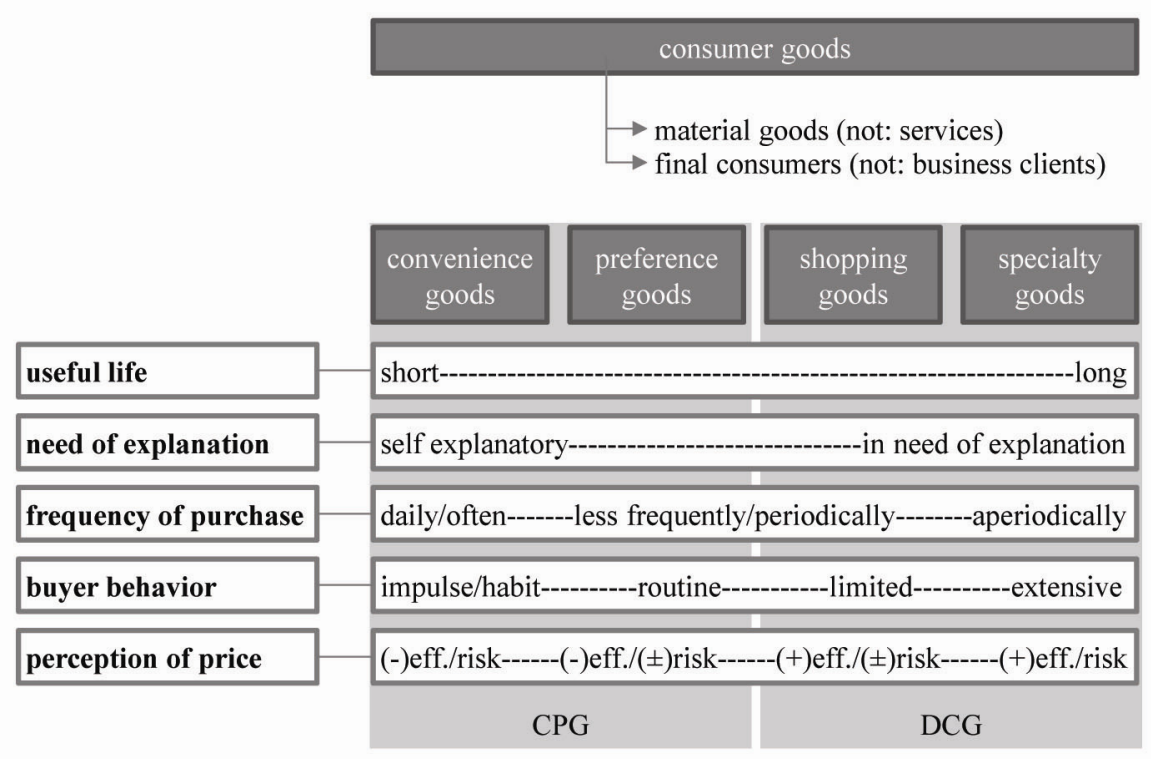

Figure 1. Categorization of consumer goods

Description: $(-)=$ low; $( \pm)=$ medium; $(+)=$ high, source: compiled by the authors based on Leischner (2009) as well as Murphy and Enis (1986).

\section{Hypothesis and Research Question}

Figure 2 summarizes our literature review and provides the theoretical framework for our study. We address shortcomings of previous research derived from the activist vs. deterministic school on a less aggregate level of analysis.

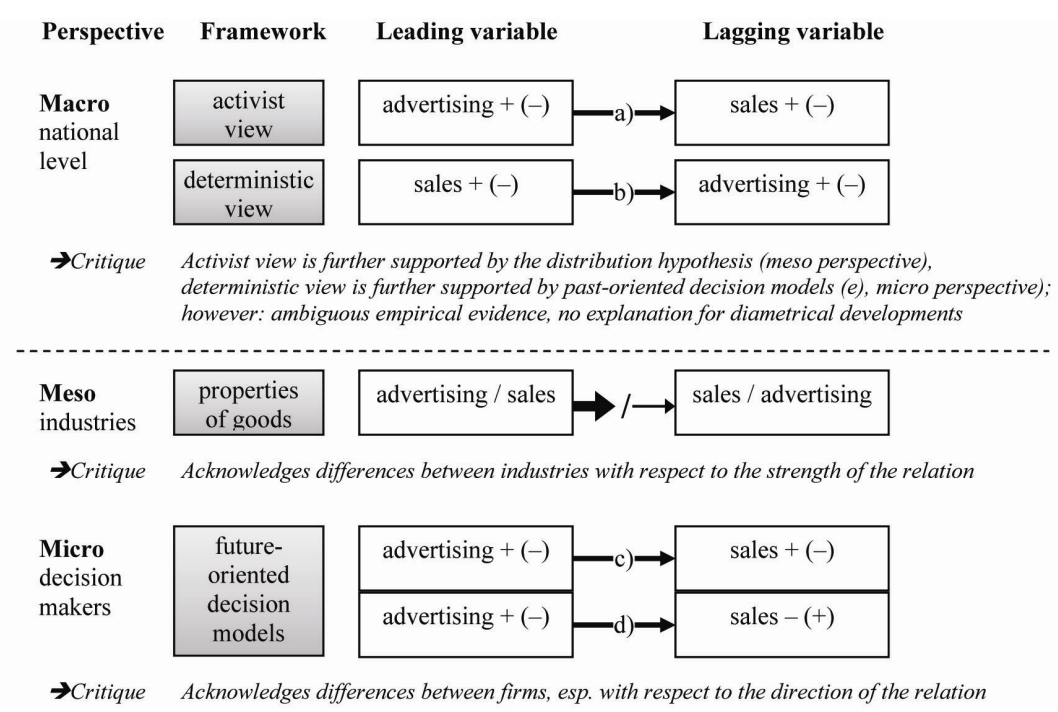

Figure 2. Theoretical framework: Scenarios for temporal relations between advertising expenditures and sales 
In detail, we draw the following conclusions: Theory and previous research have shown that due to different product characteristics, sales for DCG depend more strongly on the economic situation than sales for CPG, and that advertising elasticities are stronger and more stable over time for DCG compared to CPG. From these insights, we formulate the following hypothesis:

H1: The advertising-sales relation is stronger for DCG than for CPG.

Moreover, we conclude that the relation between advertising and sales should be further investigated on industry level, and that aggregate advertising expenditures might pro-actively lead or re-actively lag sales depending on the current economic situation of a firm and its advertising budgeting approach. Therefore, we ask:

RQ1: What is the direction of influence between advertising expenditures and sales in different industries?

\section{Method}

\subsection{Sample and Procedures}

This study analyzes the relation between advertising expenditures by industry as an indicator of advertising activity and sales, controlling for available household income, GDP, and total exports for German industries. Following van der Wurff et al. (2008), exportation has to be taken into account: products that are exported are not advertised in the home country which is why the impact of sales on advertising should be weaker. This is especially important for the German automobile industry. The observed industries comprise food, drinks, tobacco, as well as health and pharmaceutics for CPGs and textiles and clothing, shoes and leather goods, as well as automobiles for DCGs. Data from Nielsen Media Research show that these industries have been among the most advertising-intensive ones for years in Germany (Zentralverband der deutschen Werbewirtschaft (ZAW), 2004; Zentralverband der deutschen Werbewirtschaft (ZAW), 2011) and several authors focused on these industries, too (see chapter 2.2), which gives us some points of reference for the evaluation of our own results. The advertising-sales relation is analyzed between the first quarter of 1991 and the fourth quarter of 2009, including the dot-com crisis in 2000 and its impact on the German advertising market. The reported observation periods are shorter due to deseasonalizing advertising expenditures, lag structure of the VAR model, missing data (tobacco and automobile), and excluding the period of car-scrap bonus for automobiles. Due to the German reunion in 1990, only German data from 1991 onward are used. Since advertising expenditures strongly decrease from 2010 onwards (as a consequence of the financial crisis) and a lack of data for the quarters thereafter, the observation period ends in 2009 q4. Compared to annual data, quarterly data may contain additional information on causal relations that can occur within one year (O'Donovan et al., 2000).

German data were selected due to the size of Germany's economy and the lack of research on German data, compared to the U.S. or U.K. data. Behind the United States, China, and Japan, Germany has the fourth largest economy in the world and the largest in Europe. Therefore, Germany may be a good comparison for results from the United States which has the largest economy in the world. Also, results can be compared to several studies on industries in European countries similar to Germany in political, economic, or social conditions.

Our data stem from different sources: data on gross advertising expenditures are from Nielsen Media Research, as published in Media Perspektiven. Sales index, GDP, and exports are from Eurostat. For food, the sales index was only available combined for food and forage production. Available household income is from the German Federal Statistical Office. All data in monetary values are deflated by the OECD Consumer Price Index to eliminate possible inflation noise.

Seasonally adjusted data series of advertising expenditure and sales index of each industry are plotted against time in Figure 3 and Figure 4. Most of the advertising expenditure curves show a severe drop in the middle of the series around the years 2000/2001 after the dotcom crisis occurred. The higher the expenditure level, the more severe was the cut back of advertising expenditures. For evaluating relations with advertising, the effect of this dotcom break is handled in dummy variables. Within the observation period, automobile, food, and health and pharmaceutics advertising expenditures were growing until 2000 (see Figure 3). After 2000, only health and pharmaceutics, food, and partly automobile advertising expenditures show a positive trend.

Sales figures are indexed to 100 for 2005 (see Figure 4). Sales for food, drinks, automobile, health and pharmaceutics, and tobacco show a positive trend throughout the observation period. Textiles and clothing sales grow negatively. Shoes and leather goods' sales are mostly stable but also grow negatively towards the end of the observation period. Health and pharmaceutics as well as the tobacco industry are regulated in terms of distribution and advertising in Germany. 


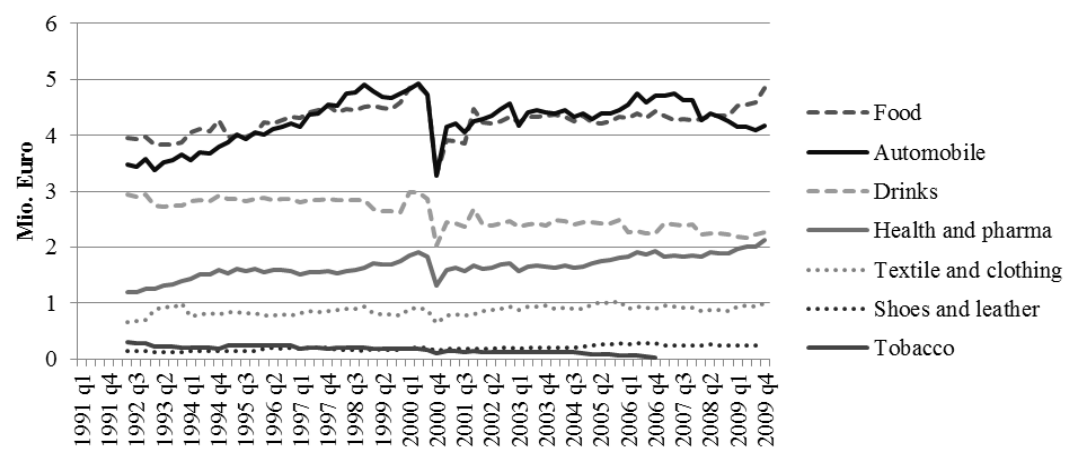

Figure 3. Advertising expenditures per industry, seasonally adjusted

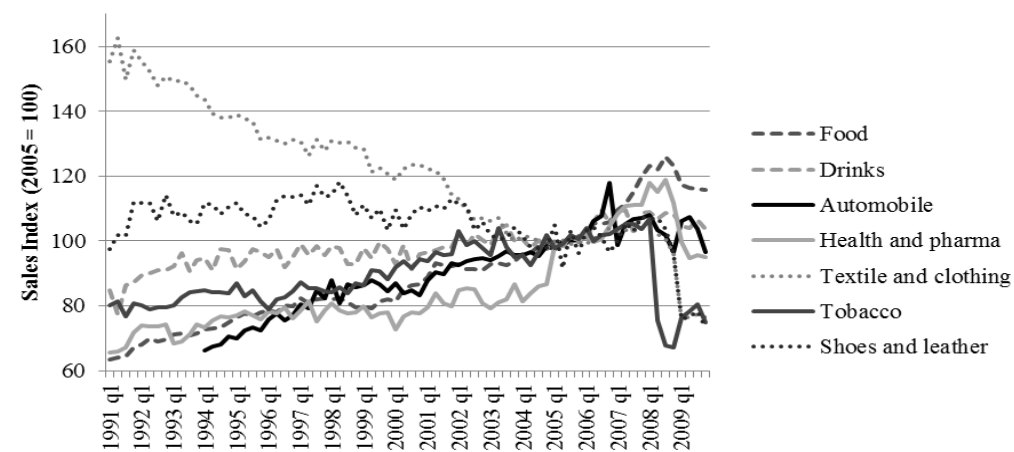

Figure 4. Sales index per industry, seasonally adjusted

\subsection{Measures}

To investigate the strength of the relation and the causal direction between real GDP, consumption, and advertising expenditures, VAR models are estimated and Granger causality tests are applied. VAR coefficients will reveal whether a causal influence is positive or negative. The more lags are significant and the higher the coefficients - given that the signs are the same - the stronger the relation. Within the following section, we briefly describe the VAR analysis and tests we used. Granger causality is used to detect whether a variable can be better predicted using another variables' past and therefore is a second inference measure for temporal leading or lagging relations between sales and advertising. The better the past of one variable predicts the future of another the stronger we interpret their relation. Granger causality reveals the direction of influence comparing the forecasting ability of e.g. sales for future advertising expenditures and vice versa.

In VAR models, each variable's dynamic development is explained by its past development as well as that of others without the a priori definition of dependent or independent variables (Sims, 1980). A VAR model ((1) and (2)) for sales $(S)$ and advertising expenditures $(A)$ including time lags, control variables household income $(I)$, GDP $(G)$ and exports $(E)$, and accounting for seasonal variation $(S V)$ and the dot-com break $(D)$ can be written

$$
\begin{aligned}
& S_{t}=\mu_{I t}+\lambda_{I I} S_{t-1}+\ldots+\lambda_{l p} S_{t-p}+\sigma_{l l} A_{t-1}+\ldots+\sigma_{I p} A_{t-p}+\pi_{l 1} I_{t-1}+\ldots+\pi_{l p} I_{t-p}+\alpha_{l} G_{t}+\beta_{1} E_{t}+\eta_{l} S V_{t}+\varsigma_{l} D_{t}+u_{l t}(1) \\
& A_{t}=\mu_{2 t}+\sigma_{21} A_{t-1}+\ldots+\sigma_{2 p} A_{t-p}+\lambda_{2 I} S_{t-1}+\ldots+\lambda_{2 p} S_{t-p}+\pi_{21} I_{t-1}+\ldots+\pi_{2 p} I_{t-p}+\alpha_{2} G_{t}+\beta_{2} E_{t}+\eta_{2} S V_{t}+\varsigma_{2} D_{t}+u_{2 t}(2)
\end{aligned}
$$

where $\mu$ is the intercept, $\lambda, \sigma, \pi, \alpha, \beta, \eta$, and $\varsigma$ are coefficients, and $u$ is the noise term. For each industry, one VAR model with all dependent, independent, and control variables is estimated. This way, many regressors are included in the model, but a maximum of mutual control is assured.

As an important demand, data must fulfill the condition of (weak) stationarity (Wooldridge, 2009). The commonly used ADF test is performed to detect unit roots and the KPSS test assesses trend and level stationarity for each time series. The first difference of the series $\left(Y_{t}-Y_{t-1}\right)$ are stationary according to ADF and KPSS test. For better comparison of coefficients between VAR models, all data are converted into percent growth rates $\left(\left(\left(Y_{t}-Y_{t-1}\right) / Y_{t-1}\right)^{*} 100\right)$ which are also stationary according to ADF and KPSS test. 
In addition, seasonal components and, for advertising expenditures, if necessary, dotcom outliers are eliminated from the series by including external dummy variables in the specified model to avoid spurious correlations (Kittel \& Winner, 2005). Therefore, the impacts of advertising expenditures and consumption within the model are free from seasonal as well as dot-com crisis effects.

The lag order of the VAR models is selected using final prediction error, Akaike's information criterion, Schwarz's Bayesian information criterion, and the Hannan and Quinn information criterion lag-order selection statistics. In addition, Wald lag exclusion statistics are obtained so as to exclude insignificant lags from the model to increase efficiency. Since the autocorrelation of residuals can lead to a misinterpretation of the relation between variables, the Durbin-Watson and Lagrange multiplier tests are performed to assure that no further information is contained in the residuals. The VAR models are estimated with the data analysis software Stata 12 using a small-sample degrees-of-freedom adjustment.

\section{Results}

For the hypothesis (H1: The advertising-sales relation is closer for DCG than for CPG.) and the research question (RQ1: What is the direction of influence between advertising expenditures and sales in different industries?), we present the advertising-sales results of the VAR model in Table 2. The $F$ value of the Granger causality test is reported in the first line of each tested direction. Significant coefficients of past lags are reported below. Autoregressive influences are not reported for brevity reasons.

With respect to hypothesis 1 , we focus on the coefficients in Table 2: The higher the coefficients and the higher the number of significant coefficients, the stronger the relationship between the two variables. In this sense, the closest relation between advertising and sales can be found for the automobile industry. Sales three quarters ago (.530) and one year ago (.667) are especially influential on advertising expenditures, but also the previous two quarters (.310 and .338) have a positive impact on advertising expenditures. For the textiles and clothing industry, sales one year ago have a significant negative impact on advertising expenditures (-5.33). That is, increasing sales lead to decreasing advertising budgets and vice versa. However, we also find tendencies for a weak positive impact of advertising expenditures of the previous quarter on current sales (.102). For the remaining DCG industry (shoes and leather goods), we only have evidence for a small and negative effect (-.146) of previous advertising expenditures on sales.

When we turn to the CPG industries, the picture is unclear: Food sales of the previous quarter impact advertising expenditures negatively $(-.365)$ which has some similarities to the results for the textile and clothing industry. For the drinks industry, sales from three quarters ago positively impact advertising expenditures (.339). However, similar to the shoes and leather goods industry, we also find a negative effect from past advertising expenditures on sales (-.222). The regulated CPG industries tobacco as well as health and pharmaceutics do not show any advertising-sales relation.

Overall, support for $\mathrm{H} 1$ is weak. Advertising expenditures strongly depend on sales for the automobile industry - which is the product group with the lowest purchase frequency under consideration. For the tobacco and health and pharmaceutics industry, we find no advertising-sales relationship at all as suggested for CPG. Results for these three industries could be interpreted as support for H1. However, for other DCG and CPG industries, we find sporadic influences between the two variables. In particular, there is no clear pattern for stronger vs. weaker advertising-sales dependencies for durable vs. consumer packaged goods.

To answer the research question on the direction of influence, comparisons between the first and second part of Table 2 as well as Granger causality tests (see $F$ ) are relevant. Regarding the latter, only in the automobile industry, changes in past sales Granger cause current changes in advertising expenditures (see $F$ ). In no other DCG or CPG industry can Granger causality be detected. For the drinks as well as textiles and clothing industry, we find weak evidence for mutual relationships since we have significant coefficients in both equations. For the shoe and leather goods industry, we only find evidence for a negative impact of past advertising expenditures on present sales. The exact opposite direction is manifested in the drinks industry where previous sales seem to impact advertising expenditures negatively.

With respect to the theoretical models, only results for the automobile industry are clearly in line with the deterministic point of view. In all other cases, we have evidence for mutual and/or negative relationships. 
Table 2. Advertising-sales relation on industry level

\begin{tabular}{|c|c|c|c|c|c|c|c|c|}
\hline \multirow{2}{*}{\multicolumn{2}{|c|}{ Characteristics }} & \multicolumn{5}{|c|}{ Purchase frequency high } & \multicolumn{2}{|c|}{ Purchase frequency low } \\
\hline & & \multicolumn{5}{|c|}{ Postponability low } & \multicolumn{2}{|c|}{ Postponability high } \\
\hline \multicolumn{2}{|l|}{ Good } & CPG & & & & DCG & & \\
\hline \multicolumn{2}{|l|}{ Industry } & Food & Drinks & Tobacco & $\begin{array}{l}\text { Health and } \\
\text { pharmaceutics }\end{array}$ & $\begin{array}{l}\text { Textiles and } \\
\text { clothing }\end{array}$ & $\begin{array}{l}\text { Shoes and } \\
\text { leather goods }\end{array}$ & Automobile \\
\hline \multirow{2}{*}{\multicolumn{2}{|c|}{ Observation period }} & 1993 q4 - & $1993 \mathrm{q} 4-$ & 1993 q3 - & 1993 q3 - & 1993 q4 - & 1993 q4 - & 1995 q4 - \\
\hline & & $2009 \mathrm{q} 4$ & 2009 q4 & $2006 \mathrm{q} 4$ & 2009 q4 & $2009 \mathrm{q} 4$ & $2009 \mathrm{q} 4$ & $2008 \mathrm{q} 1$ \\
\hline \multirow{7}{*}{$\begin{array}{l}\text { Past sales } \\
\downarrow \\
\text { Present } \\
\text { advertising } \\
\text { expenditures }\end{array}$} & $F$ & n.s. & n.s. & n.s. & n.s. & n.s. & n.s. & $3.541^{*}$ \\
\hline & $\lambda_{2 t-1}$ & $-.365^{*}$ & n.s. & n.s. & n.s. & n.s. & n.s. & $.310^{\circ}$ \\
\hline & $\lambda_{2 t-2}$ & n.s. & n.s. & n.s. & n.s. & excl. & n.s. & $.338^{\circ}$ \\
\hline & $\lambda_{2 t-3}$ & n.s. & $.339 *$ & n.s. & n.s. & excl. & excl. & $.530^{*}$ \\
\hline & $\lambda_{2 t-4}$ & n.s. & n.s. & n.s. & n.s. & $-.553^{*}$ & n.s. & $.667^{* *}$ \\
\hline & $\lambda_{2 t-5}$ & n.s. & n.s. & excl. & excl. & excl. & n.s. & excl. \\
\hline & $\lambda_{2 t-6}$ & excl. & excl. & excl. & excl. & excl. & excl. & n.s \\
\hline \multirow{3}{*}{$\begin{array}{l}\text { Past advertising } \\
\text { expenditures } \\
\downarrow\end{array}$} & $F$ & n.s. & n.s. & n.s. & n.s. & n.s. & n.s. & n.s. \\
\hline & $\sigma_{l t-1}$ & n.s. & n.s. & n.s. & n.s. & $.102^{\circ}$ & $-.146^{\circ}$ & n.s. \\
\hline & $\sigma_{l t-2}$ & n.s. & $-.222 *$ & n.s. & n.s. & excl. & n.s. & n.s. \\
\hline \multirow[t]{4}{*}{ Present sales } & $\sigma_{l t-3}$ & n.s. & n.s. & n.s. & n.s. & excl. & excl. & n.s. \\
\hline & $\sigma_{l t-4}$ & n.s. & n.s. & n.s. & n.s. & n.s. & n.s. & n.s. \\
\hline & $\sigma_{l t-5}$ & n.s. & n.s. & excl. & excl. & excl. & n.s. & excl. \\
\hline & $\sigma_{l t-6}$ & excl. & excl. & excl. & excl. & excl. & excl. & n.s \\
\hline
\end{tabular}

Description: excl.=lag excluded from estimation, n.s. $=$ not significant on $90 \%$ level, ${ }^{\circ}=$ significant on $10 \%$ level, ${ }^{*}=$ significant on $5 \%$ level, $* *=$ significant on $1 \%$ level, source: authors.

\section{Discussion}

It is not possible to generalize the advertising-sales relation in CPG and DCG. Although advertising expenditures strongly depend on past sales for the automobile industry, DCG advertising expenditures do not show a sales dependency throughout, but also CPG advertising expenditures depend on sales. However, contrary to the deterministic view, the relation is not always positive except for the drinks industry. Consequently, negative influences of past sales as found for food as well as shoes and leather goods might indicate an anti-cyclical advertising strategy which is not accounted for by the deterministic view.

With respect to the activists' point of view, we find only punctual evidence in the textiles and clothing industry. However, this result is at the same time counteracted by evidence for the opposite direction of influence. Overall, advertising expenditures were not found to increase total sales of industries according to the activist view as in Jolodar and Ansari (2011). This result is in line with the distribution hypothesis (Broadbent, 2008; Simon, 1970). High market saturation might account for the inability of advertising to further stimulate demand. Nevertheless, a shift of market shares caused by advertising activities might be detected within an industry. On a meso perspective, replicas of this study could be performed with data from growing markets in order to clarify if or to what extent the degree of market saturation affects adverting's ability to stimulate sales.

Despite the somehow cluttered results, interesting patterns are observable. When CPG sales influence advertising expenditures this impact is rather short-term. When DCG sales influence advertising expenditures this impact is rather long-term. This is in line with Sethuraman's et al. (2011) meta-analysis showing that that the advertising elasticity is higher for durable goods than for frequently purchased goods.

The results give also rise to further considerations with respect to the budgeting process on firm level - especially for those cases where we find negative signs indicating reversed relations between advertising and sales that likewise cannot be explained by the activist or deterministic perspective. E. g., the two incidences where past sales have a negative impact on advertising (food as well as textile and clothing industry) could be interpreted as past-oriented, anti-cyclical advertising strategies. Research has shown the effectiveness of anti-cyclical advertising (Frankenberger \& Graham, 2003; Kamber, 2002) or proactive approaches during recessions (Srinivasan, Rangaswamy, \& Lilien, 2005) which was emphasized again more recently (Quelch \& Jocz, 2009). However, both seem less prominent among practitioners. Future research could reveal the factors that hinder the usage of anti-cyclical advertising strategies. 
There are also two values indicating a negative impact from past advertising expenditures to current sales for drinks as well as shoes and leather goods. This could be construed as a result of future-oriented budget setting approaches as outlined in section 2.1: If advertisers expect correctly that sales will decrease (increase) "tomorrow", and an anti-cyclical strategy is pursued, they might increase (decrease) their advertising budgets "today". If a pro-cyclical advertising strategy was intended, assumptions about the future development of sales must have been wrong. In any case, for these two scenarios, a true causal relation (extending a Granger causal relation) can be precluded. However, sales expectations might serve as an explanatory variable for advertising expenditure changes.

It has to be kept in mind that changes in advertising expenditures rely on many further factors such as the overall communication strategy, market structure, pricing strategy, product life cycle, advertising goals etc., which may vary within industries and among companies or over time. Furthermore, advertising activities might not always aim directly at sales effects or might fail to do so. Although agency practitioners believe that advertising has to be creative and varied over time to work effectively (Nyilasy \& Reid, 2009a; Nyilasy \& Reid, 2009b), advertising expenditures and copy as well as advertising effectiveness and sales are related but do not cause one another. Different copy with different communication goals for the same brand may have vastly different sales responses (Jones, 2004; Taylor, Kennedy, \& Sharp, 2009) and advertising expenditures are only one factor for advertising effectiveness. More research is necessary to explain advertising budgeting decision making. This study did not account for other communication instruments used to communicate to consumers due to a lack of data and complexity of modeling. Nevertheless, advertising is one of the most important communication instruments within strategic communication for consumer goods (Kotler, 2009). Therefore we assume that incorporating other communication instruments will complement our findings but not change them fundamentally.

We believe that our findings may well be transferred to CPG and DCG industries of other countries since principles of purchase frequency and postponability of CPG and DCG are similar in any country. However, when the industries' structure or the market form greatly differs (e.g., oligopoly vs. polypoly), the sales-advertising relation may differ as well. However, differences may not only occur within industries but also within companies. Future research could further delve into the power relations within a company that might highly influence the process and size of advertising budgets. As mentioned above, anti-cyclical approaches are less often used and this could be related to managers' restricted autonomy of decision or, more generally speaking, to power relations within an organization. Accordingly, qualitative and more in-depth studies would be a welcome addition to the quantitative approaches.

\section{Summary and Conclusion}

This study provides insight into the advertising budgeting logic of an industry assessing the relation between sales and advertising expenditures controlling for available household income, exports, and GDP for four consumer packaged goods industries and three durable consumer goods industries. Although theory suggests a closer advertising-sales relation for DCG than for CPG, no uniform picture can be drawn from our results. We found that advertising budgeting can be forecasted by past sales and partly by future sales expectations. Past sales drive advertising expenditures in a pro-cyclical manner in the drinks and automotive industry but in an anti-cyclical manner in the food as well as textiles and clothing industry. The impact of past sales is strongest for automobile advertising expenditures which we expected from theory. Automobile advertising expenditures strongly depend on sales up to one year ago. Because car purchases depend on income and the economic situation, and are highly postponable, advertisers cut down their budgets in times of economic downturns assuming that demand and thus sales cannot be stimulated anyway.

We assume that the use of strategic communication instruments underlie past or expected sales development. To complement the activist and deterministic views we suggest an assumptionist view accounting for future-oriented advertising budgeting setting based on sales expectations. Hence, sales may change company and marketing goals that eventually affect communication goals and instruments. This close involvement of strategic communication and company success complicates disentangling the direction of influence. That is why modeling relations on industry or country level will fail to show a unified picture.

For managers, our analysis reveals advertising-sales relations for an entire industry, i.e., for all competitors' sales and advertising expenditures on average (controlling for seasonality). Therefore, future advertising expenditures of an industry can be forecasted on past sales figures of this industry. That is, when food sales decline, a typical food company will increase advertising in the next quarter. When drinks' sales decline, advertising will decline as well in three quarters. When textiles and clothing sales decline, advertising will increase the next year. When 
automobile sales increase, advertising increases as well. However, for tobacco and health or pharmaceutical companies, forecasting based on past sales was not possible. Also, to forecast future sales based on advertising expenditures was rarely possible. Hence, when a company wants to stand out from the competitor's advertising budgeting strategy, they can budget their advertising expenditures contrary to the logic of their industry. Especially for the automobile industry, in times of low sales or economic downswings, advertising may keep the brand at the back of the consumers' mind and become effective as soon as the income situation improves.

\section{Acknowledgements}

This study was conducted for the project "The Impact of Changes in Advertising on the Media", funded by the Swiss National Science Foundation.

\section{References}

Andrews, R. L., \& Franke, G. R. (1991). The determinants of cigarette consumption: A meta-analysis. Journal of Public Policy \& Marketing, 10(1), 81-100.

Ashley, R., Granger, C. W. J., \& Schmalensee, R. (1980). Advertising and aggregate consumption: An analysis of causality. Econometrica, 48(5), 1149-1167. http://dx.doi.org/10.2307/1912176

Bagwell, K. (2001). The economics of advertising. The international library of critical writings in economics. Cheltenham: Elgar. Retrieved from http://www.gbv.de/dms/hbz/toc/ht013424801.pdf

Balasubramanian, S. K., \& Kumar, V. (1990). Analyzing variations in advertising and promotional expenditures: Key correlates in consumer, industrial, and service markets. Journal of Marketing, 54(2), 57-68. http://dx.doi.org/10.2307/1251870

Berndt, R. (2005). Marketingstrategie und Marketingpolitik (4th ed.). Berlin: Springer.

Brierley, S. (2006). The advertising handbook (2nd ed.). London: Routledge.

Broadbent, T. (2008). Does advertising grow markets? International Journal of Advertising, 27(5), 745-770. http://dx.doi.org/10.2501/S0265048708080335

Broadbent, T. (2009). FMCG advertising: the home of branding. In H. Powell (Ed.), Media practice. The advertising handbook (3rd ed., pp. 162-173). London: Routledge.

Bryant, J., \& Zillmann, D. (Eds.). (1994). Media effects: advances in theory and research. Hillsdale, NJ: Lawrence Erlbaum Associates.

Cavusgil, E., \& Calantone, R. (2011). Are pharmaceutical marketing decisions calibrated to communications effects? Health Marketing Quarterly, 28(4), 317-336. http://dx.doi.org/10.1080/07359683.2011.623105

Cheong, Y., Kim, K., \& Kim, H. (2013). Advertising and promotion budgeting during volatile economic conditions: Factors influencing the level of decentralisation in budgeting and its relations to budget size and allocation. International Journal of Advertising, 32(1), 143-162. http://dx.doi.org/10.2501/IJA-32-1-143-162

Chowdhury, A. R. (1994). Advertising expenditures and the macro-economy: Some new evidence. International Journal of Advertising, 13(1), 1-14.

Cook, S. (1999). Cyclicality and durability: Evidence from U.S. consumers' expenditure. Journal of Applied Economics, 2(2), 299.

Deleersnyder, B., Dekimpe, M. G., Steenkamp, J.-B. E. M., \& Leeflang, P. S. H. (2009). The role of national culture in advertising's sensitivity to business cycles: An investigation across continents. Journal of Marketing Research (JMR), 46(5), 623-636. http://dx.doi.org/10.1509/jmkr.46.5.623

Dhawan, R., \& Jeske, K. (2008). Energy price shocks and the macroeconomy: The role of consumer durables. Journal of Money, Credit and Banking, 40(7), 1357-1377. http://dx.doi.org/10.1111/j.1538-4616.2008.00163.x

Draganska, M., \& Klapper, D. (2011). Choice set heterogeneity and the role of advertising: An analysis with micro and macro data. Journal of Marketing Research (JMR), 48(4), 653-669. http://dx.doi.org/10.1509/jmkr.48.4.653

Dutt, A. K. (2008). The dependence effect, consumption and happiness: Galbraith revisited. Review of Political Economy, 20(4), 527-550. http://dx.doi.org/10.1080/09538250802308919

Engle, B., \& Ambler, T. (2002). The influence of advertising on the demand for chocolate confectionery. 
International Journal of Advertising, 21(4), 437-454.

Ewing, M. T., \& Jones, J. P. (2000). Agency beliefs in the power of advertising. International Journal of Advertising, 19(3), 335-348.

Farris, P., Verbeke, W., Mdickson, P., \& van Nierop, E. (1998). Path dependencies and the long-term effects of routinized marketing decisions. Marketing Letters, 9(3), 247-268. http://dx.doi.org/10.1023/A:1008068105807

Farris, P. W., \& Buzzell, R. D. (1979). Why advertising and promotional costs vary: Some cross-sectional analyses. Journal of Marketing, 43(4), 112-122. http://dx.doi.org/10.2307/1250277

Fischer, M., \& Albers, S. (2010). Patient- or physician-oriented marketing: What drives primary demand for prescription drugs? Journal of Marketing Research, 47(1), $103-121$. http://dx.doi.org/10.1509/jmkr.47.1.103

Frankenberger, K. D., \& Graham, R. C. (2003). Should firms increase advertising expenditures during recessions? Retrieved from http://www.premierguitar.com/About/pdf/Value_of_Advertising.pdf

Galbraith, J. K. (1967). The new industrial state (3rd ed.). Boston: Houghton Mifflin.

Grewal, R., Mehta, R., \& Kardes, F. R. (2004). The timing of repeat purchases of consumer durable goods: The role of functional bases of consumer attitudes. Journal of Marketing Research (JMR), 41(1), 101-115. http://dx.doi.org/10.1509/jmkr.41.1.101.25090

Hallahan, K., Holtzhausen, D., van Ruler, B., Verčič, D., \& Sriramesh, K. (2007). Defining strategic communication. International Journal of Strategic Communication, 1(1), 3-35. http://dx.doi.org/10.1080/15531180701285244

Helgesen, T. (1992). The rationality of advertising decisions: Conceptual issues and some empirical findings from a Norwegian study. Journal of Advertising Research, 32(6), 22-30.

Hsu, M. K., Darrat, A. F., Maosen, Z., \& Abosedra, S. S. (2002). Does advertising stimulate sales or mainly deliver signals? A multivariate analysis. International Journal of Advertising, 21(2), 175-195.

Hung, C. L., \& West, D. C. (1991). Advertising budgeting methods in Canada, the UK and the USA. International Journal of Advertising, 10(3), 239-250.

Hutchinson, J. W., Alba, J. W., \& Eisenstein, E. M. (2010). Heuristics and biases in data-based decision making: Effects of experience, training, and graphical data displays. Journal of Marketing Research, 47(4), 627-642. http://dx.doi.org/10.1509/jmkr.47.4.627

Jolodar, S. Y. E., \& Ansari, M. E. (2011). An investigation of TV advertisement effects on customers' purchasing and their satisfaction. International Journal of Marketing Studies, 3(4), 175-181.

Jones, J. P. (2004). A counter-attack from the ivory tower. International Journal of Advertising, 23(4), 523-526.

Jones, J. P. (2007). When ads work: New proof that advertising triggers sales (2nd ed.). Armonk, N.Y: Sharpe.

Jung, C., \& Seldon, B. J. (1995). The macroeconomic relationship between advertising and consumption. Southern Economic Journal, 61(3), 577-587. http://dx.doi.org/10.2307/1060982

Kamber, T. (2002). The brand manager's dilemma: Understanding how advertising expenditures affect sales growth during a recession. Journal of Brand Management, 10(2), 106-120. http://dx.doi.org/10.1057/palgrave.bm.2540109

Kaytaz, M., \& Gul, M. C. (2014). Consumer response to economic crisis and lessons for marketers: The Turkish experience. Journal of Business Research, 67(1), 2701-2706. http://dx.doi.org/10.1016/j.jbusres.2013.03.019

Kienzler, S., \& Lischka, J. (2013). Von proaktiv zu reaktiv?: Implikationen einer Makro-Analyse zum Werbeverhalten in Deutschland 1991-2009. In T. Schierl \& J. Tropp (Eds.), Wert und Werte der Marketingkommunikation (pp. 153-171). Köln: von Halem.

King, R. G., \& Rebelo, S. T. (1999). Resuscitating real business cycles. In J. B. Taylor \& M. Woodford (Eds.), Handbooks in economics: 15,1,A. Handbook of macroeconomics (pp. 927-1007). Amsterdam [u.a.]: North Holland.

Kittel, B., \& Winner, H. (2005). How reliable is pooled analysis in political economy? The globalization-welfare state nexus revisited. European Journal of Political Research, 44(2), $269-293$. 
http://dx.doi.org/10.1111/j.1475-6765.2005.00228.x

Kopf, D. A., Torres, I. M., \& Enomoto, C. (2011). Advertising's unintended consequence. Journal of Advertising, 40(4), 5-18. http://dx.doi.org/10.2753/JOA0091-3367400401

Kotler, P. (2009). Marketing management. Harlow: Pearson Prentice Hall.

Kotler, P., Keller, K. L., \& Bliemel, F. (2007). Marketing-management: Strategien für wertschaffendes Handeln (12th ed.). München: Pearson Studium.

Krishna, K., \& Yavas, C. (2004). Lumpy consumer durables, market power, and endogenous business cycles. Canadian Journal of Economics/Revue Canadienne d'Economique, 37(2), 375-391. http://dx.doi.org/10.1111/j.0008-4085.2004.00007.x

Lamdin, D. J. (2008). Galbraith on advertising, credit, and consumption: A retrospective and empirical investigation with policy implications. Review of Political Economy, 20(4), 595-611. http://dx.doi.org/10.1080/09538250802308984

Lamey, L., Deleersnyder, B., Dekimpe, M. G., \& Steenkamp, J.-B. E. M. (2007). How business cycles contribute to private-label success: Evidence from the United States and Europe. Journal of Marketing, 71(1), 1-15. http://dx.doi.org/10.1509/jmkg.71.1.1

Leischner, E. (2009). Kommunikation für Konsumgüter. In M. Bruhn, F.-R. Esch, \& T. Langner (Eds.), Handbuch Kommunikation. Grundlagen - innovative Ansätze - praktische Umsetzungen (pp. 1077-1099). Wiesbaden: Gabler.

McCollough, J. (2007). The effect of income growth on the mix of purchases between disposable goods and reusable goods. International Journal of Consumer Studies, 31(3), 213-219. http://dx.doi.org/10.1111/j.1470-6431.2006.00504.x

Meffert, H. (2000). Marketing: Grundlagen marktorientierter Unternehmensführung;Konzepte - Instrumente Praxisbeispiele (9th ed.). Wiesbaden: Gabler. http://dx.doi.org/10.1007/978-3-322-93168-9

Molinari, B., \& Turino, F. (2006). The role of advertising in the aggregate economy: The working-spending cycle. Retrieved from http://sugarhoover.co.uk/articulosrecibidos/Molinari-Turino.pdf

Murphy, P. E., \& Enis, B. M. (1986). Classifying products strategically. Journal of Marketing, 50(3), $24-42$. http://dx.doi.org/10.2307/1251583

Nyilasy, G., \& Reid, L. N. (2009a). Agency practitioner theories of how advertising works. Journal of Advertising, 38(3), 81-96. http://dx.doi.org/10.2753/JOA0091-3367380306

Nyilasy, G., \& Reid, L. N. (2009b). Agency practitioners' meta-theories of advertising. International Journal of Advertising, 28(4), 639-668. http://dx.doi.org/10.2501/S0265048709200801

O'Donovan, B., Rae, D., \& Grimes, A. (2000). Determinants of advertising expenditures: Aggregate and cross-media evidence. International Journal of Advertising, 19(3), 317-334.

Petersen, B., \& Strongin, S. (1996). Why are some industries more cyclical than others? Journal of Business and Economic Statistics, 14(2), 189-198.

Picard, R. G. (2001). Effects of recessions on advertising expenditures: An exploratory study of economic downturns in nine developed nations. Journal of Media Economics, 14(1), 1-14. http://dx.doi.org/10.1207/S15327736ME1401_01

Poser, G. (1983). Macroeconomic implications of curtailment and life-cycle change. Advances in Consumer Research, 10(1), 163-168.

Power, J. (2004). Durable spending, relative prices and consumption. Bank of England Quarterly Bulletin, 44(1), $21-31$. Retrieved

from http://www.bankofengland.co.uk/publications/Documents/quarterlybulletin/qb040101.pdf

Prendergast, G., West, D., \& Shi, Y.-Z. (2006). Advertising budgeting methods and processes in China. Journal of Advertising, 35(3), 165-176. http://dx.doi.org/10.2753/JOA0091-3367350310

Quarles, R. C., \& Jeffres, L. W. (1983). Advertising and national consumption: A path analytic re-examination of the Galbraithian argument. Journal of Advertising, 12(2), 4-33. http://dx.doi.org/10.1080/00913367.1983.10672835

Quelch, J. A., \& Jocz, K. E. (2009). How to market in a downturn. Harvard Business Review, 87(4), 52-62. 
Rehme, G., \& Weisser, S. F. (2007). Advertising, consumption and economic growth: An empirical investigation. Retrieved from http://www.econstor.eu/handle/10419/32093

Sethuraman, R., Tellis, G. J., \& Briesch, R. A. (2011). How well does advertising work? Generalizations from meta-analysis of brand advertising elasticities. Journal of Marketing Research, 48(3), 457-471. http://dx.doi.org/10.1509/jmkr.48.3.457

Simon, J. L. (1970). Issues in the economics of advertising. Urbana, Ill: Univ. of Illinois Press.

Sims, C. (1980). Macroeconomics and reality. Econometrica, 48(1), 1-48. http://dx.doi.org/10.2307/1912017

Srinivasan, R., Rangaswamy, A., \& Lilien, G. L. (2005). Turning adversity into advantage: Does proactive marketing during a recession pay off? International Journal of Research in Marketing, 22(2), 109-125. http://dx.doi.org/10.1016/j.jiresmar.2004.05.002

Stock, J. H., \& Watson, M. W. (1999). Business cycle fluctuations in US macroeconomic time series. In J. B. Taylor \& M. Woodford (Eds.), Handbooks in economics: 15,1,A. Handbook of macroeconomics (pp. 3-64). Amsterdam [u.a.]: North Holland.

Sturgess, B. T., \& Wilson, N. (1984). Advertising expenditure and aggregate consumption in Britain and West Germany: An analysis of causality. Managerial and Decision Economics, 5(4), 219-227. http://dx.doi.org/10.1002/mde.4090050406

Taylor, J., Kennedy, R., \& Sharp, B. (2009). Is once really enough? Making generalizations about advertising's convex sales response function. Journal of Advertising Research, 49(2), 198-200. http://dx.doi.org/10.2501/S002184990909028X

Taylor, L. D., \& Weiserbs, D. (1972). Advertising and the aggregate consumption function. American Economic Review, 62(4), 642-655.

Tellis, G. J., \& Tellis, K. (2009). Research on advertising in a recession: A critical review and synthesis. Journal of Advertising Research, 49(3), 304-327. http://dx.doi.org/10.2501/S0021849909090400

Turner, P. (2000). Aggregate advertising, sales volume and relative prices in the long run. Applied Economics Letters, 7(8), 505-508. http://dx.doi.org/10.1080/13504850050033265

Van der Wurff, R., Bakker, P., \& Picard, R. G. (2008). Economic growth and advertising expenditures in different media in different countries. Journal of Media Economics, 21(1), 28-52. http://dx.doi.org/10.1080/08997760701806827

West, D., \& Prendergast, G. P. (2009). Advertising and promotions budgeting and the role of risk. European Journal of Marketing, 43(11/12), 1457-1476. http://dx.doi.org/10.1108/03090560910989984

Wilcox, G. B., Kamal, S., \& Gangadharbatla, H. (2009). Soft drink advertising and consumption in the United States 1984-2007. International Journal of Advertising, 28(2), 351-367. http://dx.doi.org/10.2501/S026504870920059X

Wilkie, W. L., \& Moore, E. S. (2007). Advertisings' performance in a market system. In G. J. Tellis \& T. Ambler (Eds.), The Sage handbook of advertising (pp.461-475). London: Sage Publications. http://dx.doi.org/10.4135/9781848607897.n29

Wooldridge, J. M. (2009). Introductory econometrics: A modern approach (4th ed.). Mason Ohio: South Western cengage learning.

Zentralverband der deutschen Werbewirtschaft (ZAW). (2004). Werbung in Deutschland 2004. Berlin: edition ZAW.

Zentralverband der deutschen Werbewirtschaft (ZAW). (2011). Werbung in Deutschland 2011. Berlin: edition ZAW.

\section{Copyrights}

Copyright for this article is retained by the author(s), with first publication rights granted to the journal.

This is an open-access article distributed under the terms and conditions of the Creative Commons Attribution license (http://creativecommons.org/licenses/by/3.0/). 